\title{
TUBEROUS SCLEROSIS MULTIMODALITY IMAGING UTILITY- A CASE REPORT
}

\author{
Arpita Mahapatra Thambaํ, Ashwini Kulkarni
}

${ }_{1}^{1}$ Associate Professor, Department of Radiology, K. J. Somaiya Medical College, Mumbai, Maharashtra.

${ }^{2}$ Resident, Department of Radiology, K. J. Somaiya Medical College, Mumbai, Maharashtra.

HOW TO CITE THIS ARTICLE: Thamba AM, Kulkarni A. Tuberous sclerosis multimodality imaging utility- a case report. J. Evolution Med. Dent. Sci. 2018;7(09):1168-1170, DOI: 10.14260/jemds/2018/266

\section{PRESENTATION OF CASE}

A 20 years old female, born of non-consanguineous marriage presented with multiple dome-shaped papules having butterfly or malar distribution. Patient has these facial lesions since 4 - 5 years of age; the size and number of the lesions is increasing with age causing cosmetic problems.

Patient had diminution of vision and history of drooping of right upper lid since childhood.

Patient also had menarche at 13 years of age. Currently, she presents with complaints of irregular menstrual cycle.

Tuberous sclerosis is an autosomal dominant neurocutaneous syndrome characterised by various abnormalities including multisystemic hamartomas. A case of tuberous sclerosis in a teenage girl is reported. The patient presented with facial fibroangiomas. With multimodality radiological investigations and based on major and minor criteria, the diagnosis of tuberous sclerosis was established.

\section{DIFFERENTIAL DIAGNOSES}

- Tuberous sclerosis.

- Multiple endocrine neoplasia-I.

- Acne vulgaris.

- Connective tissue nevus.

\section{CLINICAL DIAGNOSIS}

- Multiple hyperpigmented dome-shaped papules on patient's face. Shagreen patches, ash-leaf macules, dental pits and oral fibromas were also noted.

- Biopsy of facial lesions was done, confirming angiofibromas.

\section{Ocular Examination}

- Visual acuity of 6/60 in right eye and 6/6 in the left eye.

- Conjunctival chemosis on right side with ptosis.

Patient also Complained of Irregular Menstrual Cycle, for which USG Abdomen and Pelvis was done. It showed-

- Bilateral enlarged ovaries (20 - $22 \mathrm{cc}$ each) with multiple small follicles arranged in periphery- suggestive of polycystic ovaries. Minimal free fluid was noted in Pouch of Douglas.

- Multiple iso to hyperechoic, round to oval lesions in bilateral renal cortices, average measuring $7-8 \mathrm{~mm}$ each, possibly multiple renal angiolipomas.

'Financial or Other Competing Interest': None.

Submission 21-11-2017, Peer Review 14-02-2018,

Acceptance 20-02-2018, Published 26-02-2018.

Corresponding Author:

Dr. Arpita Mahapatra Thamba,

Bungalow No. 17,

Bharat Tirth Society, Chembur,

Mumbai-400071, Maharashtra.

E-mail: arpita_rad@yahoo.com

DOI: $10.14260 / \mathrm{jemds} / 2018 / 266$

(c) (1) $(9)$
- Further radiological investigations were advised including CT Brain, CT Thorax, CT abdomen + pelvis (plain + contrast).

\section{CT Brain-}

Multiple calcific foci of periventricular hyperattenuation are noted- suggestive of calcific subcortical tubers-

- Rest of the brain parenchyma appears normal.

- Posterior fossa remains normal.

- Bony calvarium is normal.

\section{CT Thorax-}

Visualised lung parenchyma appears normal; however, mild pericardial effusion.

\section{CT Abdomen + Pelvis (Plain + Contrast)-}

- Right kidney measures $8.9 \times 3.8 \times 5.0 \mathrm{~cm}$. (SI x AP x trans).

- Left kidney measures 10 x 3.4 x $5.2 \mathrm{~cm}$ (SI x AP x trans).

- Both kidneys appear bulky in axial (transverse) dimension.

- Multiple small hypodense lesions with smooth and welldefined contours and having attenuation of -17 to $-80 \mathrm{HU}$ are noted in bilateral renal cortices. Larger lesions measuring $1-1.1 \mathrm{~cm}$ each and smaller lesions measuring 0.3 - $3.5 \mathrm{~mm}$ each, suggestive of angiomyolipomas.

- No intrarenal or perirenal collections are seen.

- Both kidneys show prompt nephrogram and good excretion of contrast.

- Bilateral ureters are normal in course and calibre.

- Urinary bladder is distended and normal.

- Bilateral ovaries are bulky (20 - 22 cc each) with polycystic appearance.

- Minimal free fluid noted in Pouch of Douglas.

- Liver is normal in size, shows normal contrast enhancement. No focal lesion. IHBR appear normal, are not dilated.

- $\quad \mathrm{GB}$ is distended and appears normal. CBD is normal.

- Pancreas appears normal.

- Spleen is normal in size, shows normal contrast enhancement with no focal lesion.

- Portal vein, splenic vein, SMV, SMA, aorta and IVC are normal.

- Bilateral adrenals are normal.

- Bowel loops are unremarkable.

- Visualised bones appear normal.

- Plain radiograph of chest was suggestive of cardiomegaly. 


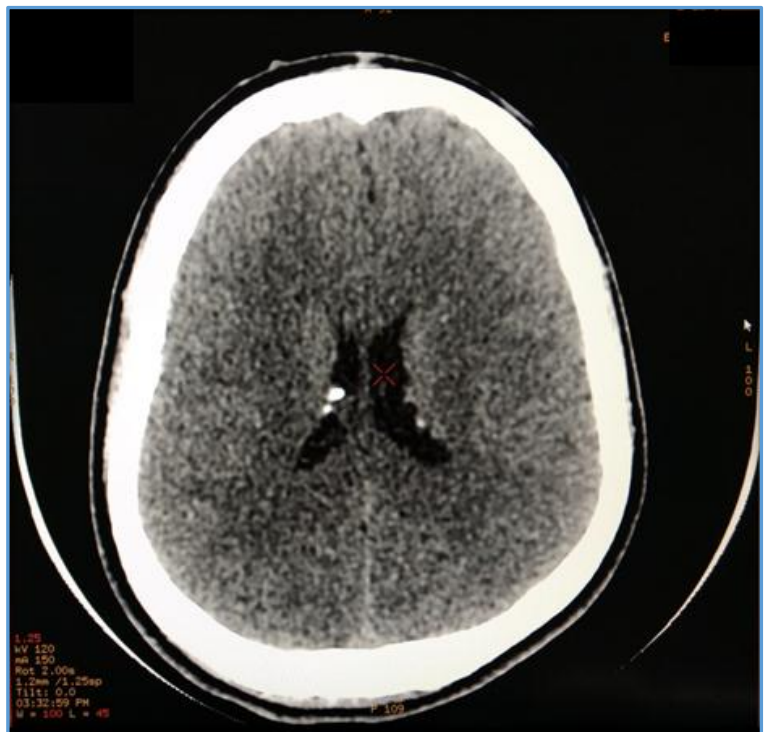

Multiple Calcific Foci of Periventricular Hyperattenuation are noted-suggestive of Calcific Subcortical Tubers

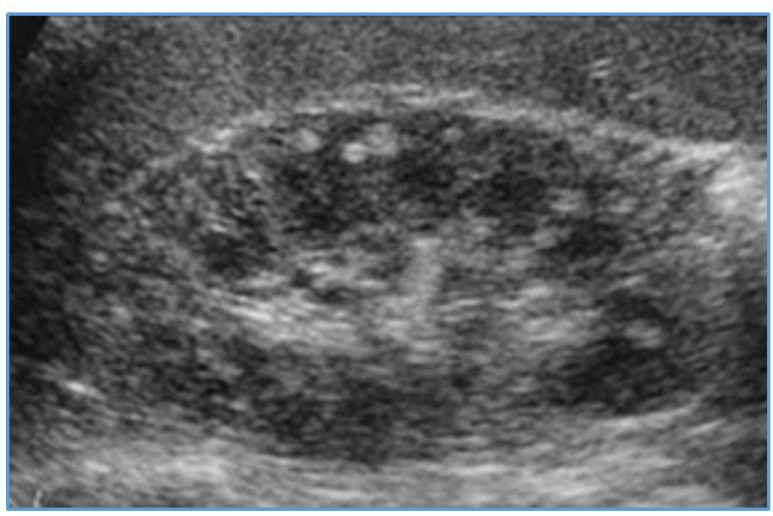

Multiple Iso to Hyperechoic, Round to Oval Lesions in Bilateral Renal Cortices, average measuring 7 - $8 \mathrm{~mm}$ each, possibly Multiple Renal Angiolipomas

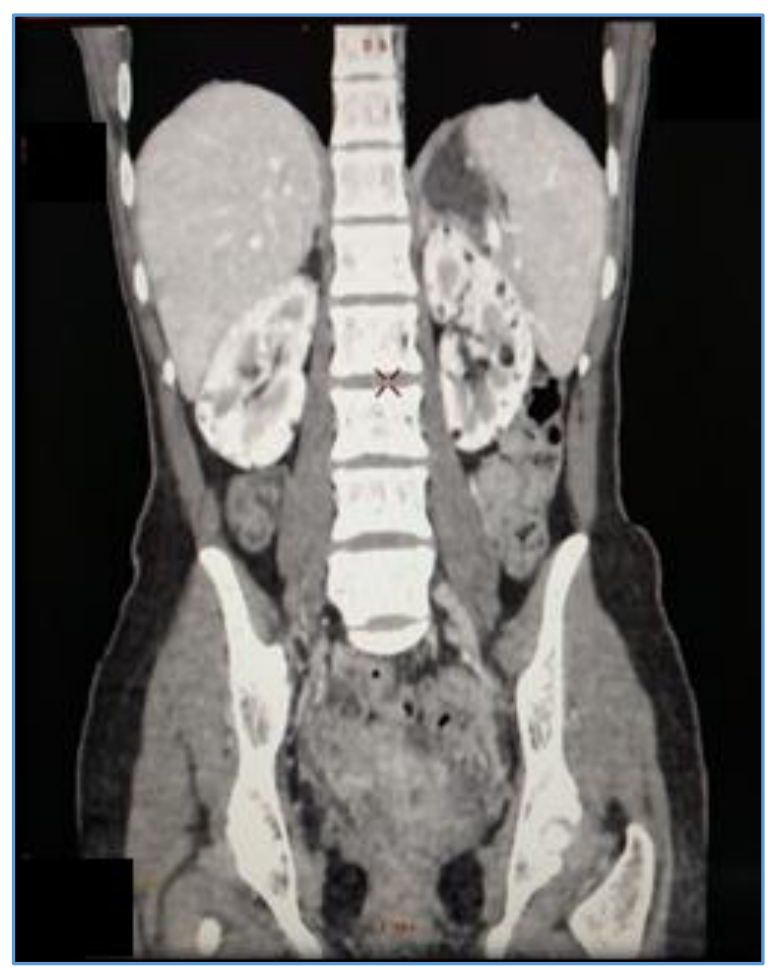

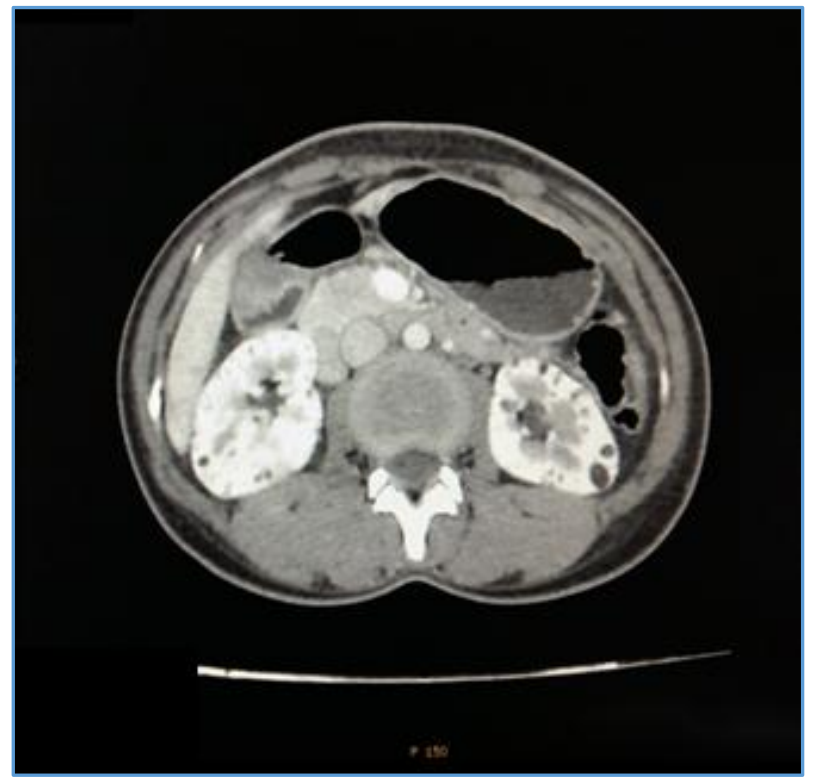

Multiple Small Hypodense Lesions with Smooth and welldefined contours and having attenuation of -17 to $-80 \mathrm{HU}$ are noted in Bilateral Renal Cortices. Larger Lesions measuring 1 - $1.1 \mathrm{~cm}$ each and Smaller Lesions measuring 0.3 - $3.5 \mathrm{~mm}$ each, suggestive of Angiomyolipomas

\section{PATHOLOGICAL DISCUSSION}

Tuberous sclerosis is a genetic disorder affecting cellular differentiation and proliferation, which results in hamartoma formation in many organs (e.g. skin, brain, eye, kidney, heart). The term 'sclerose tubereuse' was coined by Desire-Magloire Bourneville, from which the name 'tuberous sclerosis' is derived.(1) It has a prevalence estimated to be 1 in 6000 with approximately 1.5 million people affected worldwide.

There is mutation of two tumour suppressor genes, TSC1 and TSC2.(2) TSC1 is located on chromosome 9q34 and encodes the protein hamartin.(3) TSC2 is located on chromosome $16 \mathrm{p} 13$ and encodes for protein tuberin. $(4,5)$ Hamartin and Tuberin interact to form heterodimers, which inhibit the mTOR signaling cascade, which is responsible for regulating cell growth and differentiation.(6) The absence of either hamartin or tuberin leads to loss of inhibition of mTOR and therefore production of multisystemic hamartomatous tumours of tuberous sclerosis. $(7,8)$

Classical triad of facial angiofibromas, seizures and mental triad was described by Henrich Vogt.(9) However, it is observed in only $30 \%-40 \%$ of cases.(10) Tuberous sclerosis is usually diagnosed in infancy or early childhood. However, the diagnosis of tuberous sclerosis can be made earlier or later.

Correct diagnosis of this syndrome is imperative, not only by detecting cutaneous manifestations at physical examination but also by recognising characteristic multimodality imaging findings.

\section{MANAGEMENT DISCUSSION}

As patient was not having any neurological or renal manifestations, no active management was decided after neurology and nephrology references. For facial angiofibromas, laser ablation was planned. 


\section{FINAL DIAGNOSIS}

In case of facial angiofibromas based on multimodality radiographic investigations, which revealed subependymal tubers as well as renal angiomyolipomas.

\begin{tabular}{|c|c|c|c|}
\hline \multicolumn{2}{|c|}{ MAJOR FEATURES } & \multicolumn{2}{|c|}{ MINOR FEATURES } \\
\hline 1 & $\begin{array}{l}\text { Hypomelanotic macules ( }>3 \text {, at least } 5-\mathrm{mm} \\
\text { diameter) }\end{array}$ & 1 & “Confetti" skin lesions \\
\hline 2 & Angiofibromas $(>3$ ) or fibrous cephalic plaque & 2 & Dental enamel pits $(>3)$ \\
\hline 3 & Ungual fibromas $(>2)$ & 3 & Intraoral fibromas $(>2)$ \\
\hline 4 & Shagreen patch & 4 & Retinal achromatic patch \\
\hline 5 & Multiple retinal hamartomas & 5 & Multiple renal cysts \\
\hline 6 & Cortical dysplasias* & 6 & Nonrenal hamartomas \\
\hline 7 & Subependymal nodules & & \\
\hline 8 & Subependymal giant cell astrocytoma & & \\
\hline 9 & Cardiac rhabdomyoma & & \\
\hline 10 & Lymphangioleiomyomatosis $(\mathrm{LAM})^{\dagger}$ & & \\
\hline 11 & Angiomyolipomas $(>2)^{\dagger}$ & & \\
\hline $\begin{array}{l}\text { Defi } \\
\text { Poss } \\
\text { *Inc } \\
\text { †A c } \\
\text { mee }\end{array}$ & $\begin{array}{l}\text { nite diagnosis: Two major features or one major } \\
\text { sible diagnosis: Either one major feature or } \geq 2 n \\
\text { ombles tubers and cerebral white matter radial } m \\
\text { ombination of the two major clinical features (LA } \\
\text { criteria for a definite diagnosis. }\end{array}$ & $\begin{array}{l}\text { hor } \mathrm{fe} \\
\text { ratio } \\
1 \text { and }\end{array}$ & $\begin{array}{l}\text { e with }>2 \text { minor features. } \\
\text { eatures. } \\
\text { lines. } \\
\text { angiomyolipomas) without other features does not }\end{array}$ \\
\hline
\end{tabular}

According to diagnostic criteria for tuberous sclerosis, definitive diagnosis is made when two major features are present or one major feature is present with $>2$ minor features.

A probable diagnosis is made when one major and one minor feature are present.

A possible diagnosis when one major or two or more minor features are present.

\section{Three of the Major Features are noted in Present Study} which are-

- Facial angiofibromas.

- Subependymal tubers.

- Renal angiomyolipomas.

Thus, the definitive diagnosis of tuberous sclerosis is established in this patient.(11)

\section{REFERENCES}

[1] Bourneville DM. Sclerose tubereuse des circonvolutions cerebrales: idiotie et epilipsie hemiplegique. Arch Neurol (Paris) 1880;1:81-91.

[2] Narayanan V. Tuberous sclerosis complex: genetics to pathogenesis. Pediatr Neurol 2003;29(5):404-9.

[3] van Slegtenhorst M, de Hoogt R, et al. Identification of the tuberous sclerosis gene TSC1 on chromosome 9q34. Science 1997;277(5327):805-8.

[4] Xu L, Sterner C, Maheshwar MM, et al. Alternative splicing of the tuberous sclerosis 2 (TSC2) gene in human and mouse tissues. Genomics 1995;27(3):47580.
[5] European Chromosome 16 Tuberous Sclerosis Consortium. Identification and characterization of the tuberous sclerosis gene on chromosome 16. Cell 1993;75(7):1305-15.

[6] van Slegtenhorst M, Nellist M, Nagelkerken B, et al. Interaction between hamartin and tuberin, the TSC1 and TSC2 gene products. Hum Mol Genet 1998;7(6):1053-7.

[7] Sancak O, Nellist M, Goedbloed M, et al. Mutational analysis of the TSC1 and TSC2 genes in a diagnostic setting: genotype-phenotype correlations and comparison of diagnostic DNA techniques in tuberous sclerosis complex. Eur J Hum Genet 2005;13(6):73141.

[8] Jones AC, Shyamsundar MM, Thomas MW, et al. Comprehensive mutational analysis of TSC1 and TSC2 and phenotypic correlations in 150 families with tuberous sclerosis. Am J Hum Genet 1999;64(5):130515.

[9] Vogt H. Zur Pathologie und pathologischen Anatomie der veschiedenen Idiotieformer. Mschr Psychiatr Neurol 1908;24:106-17.

[10] Maria BL, Deidrick KM, Roach ES, et al. Tuberous sclerosis complex: pathogenesis, diagnosis, strategies, therapies and future research directions. J Child Neurol 2004;19(9):632-42.

[11] http://www.tscanada.ca/patientscaregivers/diagnosis-criteria-for-tsc/ 